\title{
The Changes in Physical Demands between Game Parts of Junior Female Handball Players
}

\author{
Rasa Mikalonytè $\dot{1}^{1}$ Rūtenis Paulauskas ${ }^{2}$ \\ Vytautas Magnus University, Academy of Education, T. Ševčenkos g. 31, LT-03111 Vilnius, Lithuania, \\ rasa.mikalonyte@vdu.lt \\ 2 Vytautas Magnus University, Academy of Education, T. Ševčenkos g. 31, LT-03111 Vilnius, Lithuania, \\ rutenis.paulauskas@vdu.lt
}

\begin{abstract}
The aim of the study was to evaluate the physical effort of young handball players by analysing the movement of players during one match. The LPS (Optime Eye X4 Catapult, Australia) device was used during the game to record the physical parameters of the players (distance, changing actions, running speed, movement in the triaxial plane). Data on player workload, distance traveled during a match may be useful to physical training coaches, who can use these parameters to select specific training methods.
\end{abstract}

Keywords: Team sport, LPS (local positioning system) system, distance, speed zones.

\section{Introduction}

Team handball is a physically demanding and complex game activity, where players work intensely for intermittent time intervals, when repeatedly performing different types of activity (Laver, Landreau, Seil, \& Popović, 2018). There is a noticeable trend for handball to become increasingly dynamic (Hatzimanouil, Giatsis, Kepesidou, Kanioglou, \& Loizos, 2017), as evidenced by the changing and increasing number of goals that become an essential quality criterion in handball (Pokrajac, 2010). High-intensity and variable-duration actions take place throughout the game (Michalsik, Aagaard, \& Madsen, 2013; Póvoas, Seabra, Ascensão, Magalhães, Soares, \& Rebelo, 2012). Handball is therefore defined as an intense team sport involving a variety of ever-changing actions 
(running, acceleration, pushing, blocks, jumps, collisions, etc.) (Gorostiaga, Granados, Ibanez, Gonzalez-Badillo, \& Izquierdo, 2006). Because of this variety of actions, it is difficult to distinguish which factor or factors are most important to win. Intermittent high-intensity physical activity dominates during the match, and this requires a good functional capacity of the body (Michalsik, Madsen \& Aagaard, 2014; Onusaityte \& Skarbalius, 2009). The recent development of the micro-technology advances has allowed to use portable local positioning systems (LPS) to track players indoor, providing better levels of validity and reliability than the standard GPS systems (Serpiello, Hopkins, Barnes, Tavrou, Duthie, Aughey, \& Ball, 2018). LPS provides us a practical method for quantifying time-motion characteristics during all forms of training. Recently using GPS or LPS we can break down activities into key movements and calculate outcomes estimates for a variety of different workouts while also tracking the amount of time it takes to complete a match (Luteberget, 2018). Athletes have to cover a distance of 50 to $90 \mathrm{~m} / \mathrm{min}$ during the game, of which $9<13 \mathrm{~m} / \mathrm{min}$ consists of high-intensity running actions, 3 to $5.5 \mathrm{~m} /$ $\mathrm{s}$ actions consist of movement in the side step and movement backwards, and from 1,5 to $3 \mathrm{~m} / \mathrm{s}$ - maximum effort running actions (Michalsik, 2011; Póvoas et al., 2012). Authors (Póvoas et al.) state that elite handball players make an average of 16 jumps, 7 throws, and 12 situations one-on-one during a game. An analysis of the match with 15 -year-old handball players showed that $501 \pm 47$ times the activity is changed during the match, $38 \pm 6$ times is a high-intensity activity that lasts from 2 to 6 seconds. The average distance covered by young handball players is $1777 \pm 264 \mathrm{~m}$, and adults cover almost double the distance, which ranges from $4464 \mathrm{~m}$ to $5088 \mathrm{~m}$ (Chelly et al., 2011). In the match, the work load of the players also varies, with both high and low workloads observed.

Studies show that on average, with 73 minutes of play, 825 changing of activity were performed with a 6 seconds interval (Povoas et al., 2012). These activities can be divided as follows: $13.8 \pm 6.1$ jumps, $6.7 \pm 4.0$ throws, $30.6 \pm 12.4$ change of directions, $20.3 \pm 15.7$ one-on-one situations. All of these player activities during play can be defined as the physical demands of the players. When they need to demonstrate their best physical actions as fast running, move sideways, jumping, change of directions, and all other kinds of movements. Performance analysis is used to examine team performance and determinants of success in team games (O’ Donoghue, 2014). The distances covered by players, the directions of movement during play provide a lot of information about the players' activities in the match, and the analysis of these actions provides an opportunity to organize training models (Manchado et al., 2013). But we found that the studies were more supported with the participation of male handball players more, but we did not find studies with adolescent female players when our selected parameters were recorded with the catapult program.

This knowledge provides us an opportunity to develop different game-based training methods however the ability to assess the most objective their impact on the game is ongoing scientific problem. 
The aim of our study was to assess young (U-16) female handball player's physical demands during simulated handball match, which would allow us to development appropriate models of physical training.

\section{Methods}

Sample. 28 female junior handball players ( $\mathrm{n}=14$ players in two teams), age $16.2 \pm 1.5$ years, body height $168.8 \pm 7.1 \mathrm{~cm}$; body mass $63.7 \pm 9.5 \mathrm{~kg}$; were recruited to participate in this study. The players had at least five years of experience in handball training (four time per week and one competition per week); they participated in the national championship (1 league) at the time of the experimental research. All procedures were done after participants written consent and received the approval of the ethics committee of the faculty of Sports and Health (Sports Education Institute), Lithuanian University of Educational sciences.

Experimental procedure: the experimental matches were played, where both teams were split in $2 \mathrm{sub}$ teams. In this way, subteams played handball matches $(2 \times 30 \mathrm{~min}$ and 10 min time out) of simulated competition according to the rules of the International Handball Federation (IHF). In dividing the teams, we relied on the fact that monitoring the workload of the players during training can assess the preparedness of the players and detect the fatigue of the players (Jones et al., 2015). Based on this, one can try out the most appropriate match strategies as the teams prepare for the match. The simulated match was played on a standard team handball court $(40 \times 20 \mathrm{~m})$ with 6 players per side (without goalkeepers) and a professional referee made decisions on play.

Not all teams have access to use catapult technology during the competition, due to some adaptation of the program to use in the courts where the match takes place, nevertheless all the data recorded during the simulation game is important in the training process. For that reason, this study format was chosen to monitor the preparation of the players for the match, so the player parameters were recorded during the simulation game as a training process part. Player's load: The motion demands were quantified only when the players were competing on the court using the local positioning system device (Optime Eye X4 Catapult, Australia) for indoor sports. We recorded total distance covered $(\mathrm{m})$, players load (AU), player load per minute, player load sideways (AU), forward and up (AU), a number of changes of directions $(\mathrm{CoD})$; distance covered in 4 speed zones $(\mathrm{m})$. The intensity of player 's work was divided into four intensity zones: walking $-0.10-1.30 \mathrm{~m} /$ sec; slow running - 1.31-3.00 m/ sec; fast running - 3.01-5.20 m / sec; sprint -> $5.21 \mathrm{sec}$ (Manchado et al., 2013). The speed was recorded into seconds and the distance covered (in meters) in each intensity zone. Player load is defined as the instantaneous change in speed, expressed as the sum of the square roots in each of the three vectors ( $\mathrm{x}, \mathrm{y}, \mathrm{z}$ axes) divided by a factor of 100 (Coutts, 2010). 


\section{Statistical analysis}

The statistical package SPSS (22.0) was used for analysis. Descriptive statistics were used to compute means (M) and standard deviations (SD), the normal distribution of the variables was assessed of samples under each condition using the Shapiro-Wilk test and visual inspection of $\mathrm{Q}-\mathrm{Q}$ plots. The differences between samples were performed using $t$-test at the level of significance of $p<0,05$, for dependent samples between first $10 \mathrm{~min}$ of the game with each $10 \mathrm{~min}$ of the game (A statistically significant difference was measured between the first 0-10 min compared to 10-20 min and 20-30 min of the first half, and 0-10 min, $10-20 \mathrm{~min}, 20-30 \mathrm{~min}-$ II half of the match). The reliability of the differences was determined according to Student's $t$ criterion, paired t-test, applying a confidence interval of $95 \%(\mathrm{p}<0.05)$, for a significant difference. Differences were also assessed using the Effect size (ES) scale: trivial $<0.2$; small 0.3-0.6; moderate $<1.2$; large > 2.0 (Hopkins, 2006).

The field players in the study sample were chosen to analyse together, regardless of their positions, as their activities in the match are quite similar, however, it is agreed in the literature that the positions of players in a game may also have and influence their specific activities. These playing positions differences are likely to be related to game nature (player rotation allowed or not), playing standard, tactical systems and tracking systems (Karcher, 2014).

\section{Results}

The results of the distance covered analysis is shown in figure 1 . The total covered distance in first $10 \mathrm{~min}$ of the match (I half) $-890.1 \pm 82.2 \mathrm{~m}$, and in II half $-849.6 \pm 74.1$ ( $p>0.05$, ES small). During the 10-20 min $837.9 \pm 82.7 \mathrm{~m}$ and $805.8 \pm 87.4 \mathrm{~m}(\mathrm{p}>0.05$, ES small), 20-30 $\mathrm{min}-810.8 \pm 85.4 \mathrm{~m}$ and $782.0 \pm 78.7 \mathrm{~m}$ (p>0.05, ES small). Overall in the first half player's total distance covered was $847.0 \pm 88.4 \mathrm{~m}$, in the second half $-813.1 \pm$ $83.6 \mathrm{~m}$ ( $\mathrm{p}>0,05$, ES small). There were no statistical differences in covered distance between I-II halves ( $>>0.05)$. During the last 10 minutes of the match (i.e. from 20 to 30 minutes in the 1st and from 50 to 60 minutes in the 2 nd half), the distance difference between halves is $100 \mathrm{~m} .50 \%$ of players ran a longer distance in the last 10 minutes of the 2 nd half than in the last 10 minutes of the 1 st half. 


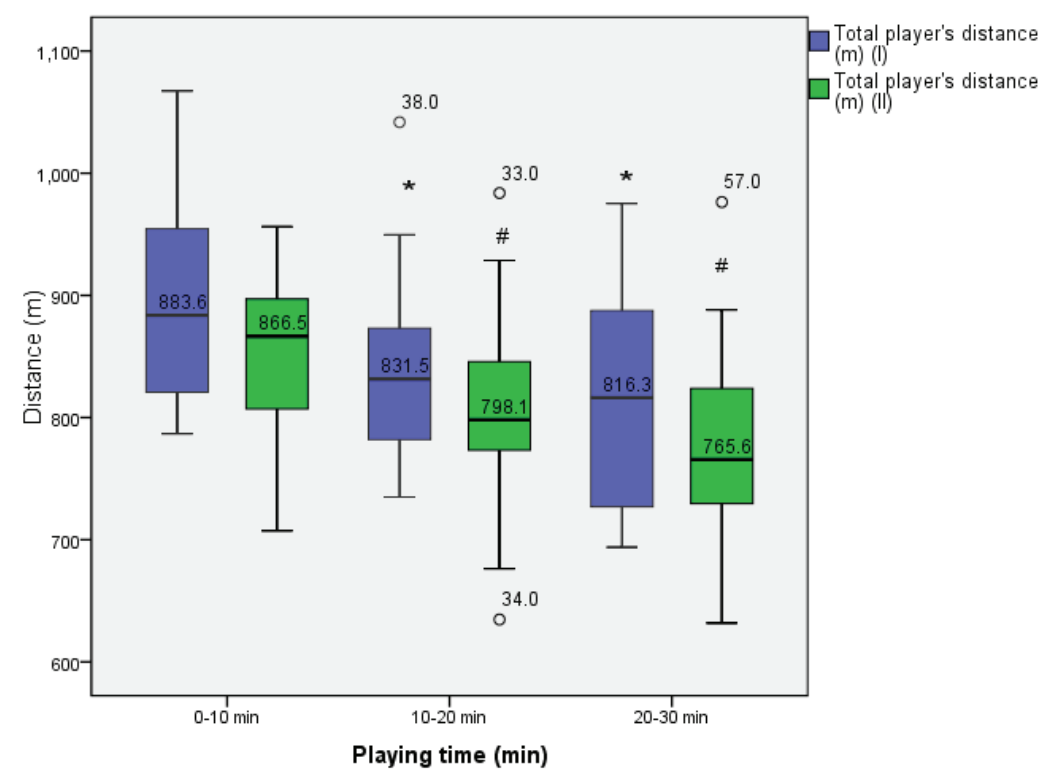

Figure 1. Total distance covered in each $10 \mathrm{~min}$ in I-II halves ( ${ }^{*}$ significant difference $0-10 \mathrm{vs}$ 10-20 $\mathrm{min}$ (I); 0-10 to 20-30 $\mathrm{min}$ (I); * significant difference 0-10 $\mathrm{min}$ (I) to 10-20 $\mathrm{min}$ (II), 20-30 $\min (I I)(p<0.05)$. Note - the median is marked in the graph.

The players load per minute are reported in figure 2. Player's load was higher in first $0-10 \mathrm{~min}$ in I-II halves $-8.7 \pm 2.9$ and $7.6 \pm 2.3 \mathrm{AU}$ ( $\mathrm{p}>0.05$, ES small); $10-20 \mathrm{~min}$ (I-II halves) $-7.0 \pm 2.6$ and $6.7 \pm 2.1 \mathrm{AU}$ ( $\mathrm{p}>0.05$, ES trivial); $20-30 \mathrm{~min}$ (I-II halves) $-6.6 \pm$ 2.6 and $6.5 \pm 1.9 \mathrm{AU}(\mathrm{p}>0.05$, ES trivial). Overall players load per minute during first half was $7.4 \pm 2.8 \mathrm{AU}$, during second half $-6.9 \pm 2.1 \mathrm{AU}(\mathrm{p}>0.05$, ES small). 


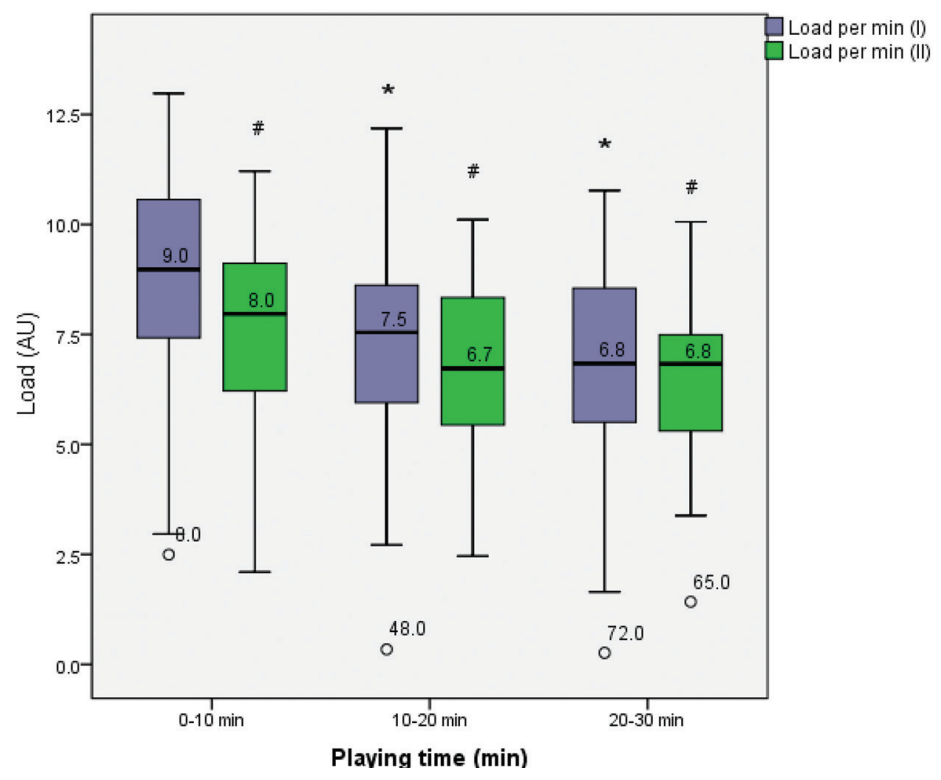

Figure 2. Player's load per min during handball simulated game according a playing time I-II halves of the match ( ${ }^{*}$ significant difference $0-10$ vs 10-20 min (I); 0-10 to 20-30 min (I);

* significant difference 0-10 $\mathrm{min}$ (I) to 0-10 $\mathrm{min}$ (II), 10-20 $\mathrm{min}$ (II), 20-30 $\mathrm{min}$ (II) ( $p<0.05$ ).

Note - the median is marked in the graph.

Total players load and load in three different axis are expressed in table 1. Player's total load in the first half was $74.3 \pm 28.4 \mathrm{AU}$, and in second half $-69.3 \pm 21.4 \mathrm{AU}(\mathrm{p}>0.05$, small ES), but there was no statistical difference between halves. The data has shown that total players load was higher in first $10 \mathrm{~min}$ of the game in both halves $(86.8 \pm 29.2 ; 76.0 \pm$ 23.2; $\mathrm{p}<0.05$, small $\mathrm{ES})$. The highest load was found when players move up $(51.9 \pm 20.6$; $48.3 \pm 15.6 ; \mathrm{p}>0.05$, small ES).

Table 1

Player's Load (total, forward, side, up in arbitrary units AU) in Handball Match, Measured Every 10 Minutes of the Match

\begin{tabular}{lccccc}
\hline $\begin{array}{c}\text { Players load } \\
\text { (AU) }\end{array}$ & $\begin{array}{c}\text { Playing } \\
\text { Time (min) }\end{array}$ & $\begin{array}{c}\text { I half } \\
\mathbf{M} \pm \text { SD }\end{array}$ & $\begin{array}{c}\text { II half } \\
\mathbf{M} \pm \text { SD }\end{array}$ & $\begin{array}{c}\text { 95\% confidence inter- } \\
\text { vals of the differences }\end{array}$ & $\begin{array}{c}\text { Effect size } \\
\text { (ES) }\end{array}$ \\
\hline $\begin{array}{l}\text { Total player } \\
\text { load (AU) }\end{array}$ & $0-10$ & $86.8 \pm 29.2$ & $76.0 \pm 23.2^{*}$ & $10.8(1.7$ to 20.0$)$ & small \\
\cline { 2 - 6 } & $10-20$ & $70.2 \pm 26.5^{*}$ & $67.3 \pm 20.5^{*}$ & $3.0(-7.9$ to 13.9$)$ & trivial \\
\cline { 2 - 6 } & $20-30$ & $65.8 \pm 26.0^{*}$ & $64.5 \pm 19.3^{*}$ & $1.3(-10.2$ to 12.7$)$ & trivial \\
\cline { 2 - 6 } & total & $74.3 \pm 28.4$ & $69.3 \pm 21.4$ & $5.0(-0.8$ to 10.9$)$ & small \\
\hline
\end{tabular}




\begin{tabular}{lccccc}
\hline $\begin{array}{l}\text { Players load } \\
\text { (AU) }\end{array}$ & $\begin{array}{c}\text { Playing } \\
\text { Time (min) }\end{array}$ & $\begin{array}{c}\text { I half } \\
\mathbf{M} \pm \text { SD }\end{array}$ & $\begin{array}{c}\text { II half } \\
\text { M } \pm \text { SD }\end{array}$ & $\begin{array}{c}\text { 95 \% confidence inter- } \\
\text { vals of the differences }\end{array}$ & $\begin{array}{c}\text { Effect size } \\
\text { (ES) }\end{array}$ \\
\hline $\begin{array}{l}\text { Player lo ad } \\
\text { FWD (AU) }\end{array}$ & $0-10$ & $30.8 \pm 11.4$ & $26.6 \pm 8.4^{*}$ & $4.3(-0.3$ to 8.8$)$ & small \\
\cline { 2 - 6 } & $10-20$ & $24.7 \pm 9.0^{*}$ & $23.5 \pm 7.2^{*}$ & $1.3(-3.0$ to 5.5$)$ & trivial \\
\cline { 2 - 6 } & $20-30$ & $23.1 \pm 9.2^{*}$ & $22.6 \pm 6.9^{*}$ & $0.5(-4.1$ to 5.0$)$ & trivial \\
\cline { 2 - 6 } & total & $26.2 \pm 10.3$ & $24.2 \pm 7.6$ & $2.0(-0.5$ to 4.5$)$ & trivial \\
\hline $\begin{array}{l}\text { Player lo ad } \\
\text { side (AU) }\end{array}$ & $0-10$ & $35.0 \pm 11.2$ & $30.8 \pm 9.0^{*}$ & $4.2(1.3$ to 7.0$)$ & moderate \\
\cline { 2 - 6 } & $10-20$ & $28.5 \pm 10.4^{*}$ & $27.3 \pm 8.1^{*}$ & $1.2(-2.7$ to 5.1$)$ & trivial \\
\cline { 2 - 6 } & $20-30$ & $26.7 \pm 10.2^{*}$ & $22.6 \pm 6.9^{*}$ & $4.1(-0.4$ to 8.5$)$ & small \\
\hline & total & $30.1 \pm 11.1$ & $26.9 \pm 8.6^{* *}$ & $3.1(1.0$ to 5.3$)$ & Small \\
\cline { 2 - 6 } $\begin{array}{l}\text { Player load up } \\
\text { (AU) }\end{array}$ & $0-10$ & $60.7 \pm 21.1$ & $53.3 \pm 17.1^{*}$ & $7.4(0.7$ to 14.1$)$ & small \\
\cline { 2 - 6 } & $20-30$ & $49.1 \pm 19.5^{*}$ & $46.9 \pm 14.9^{*}$ & $2.2(-5.9$ to 10.3$)$ & trivial \\
\cline { 2 - 6 } & total & $51.9 \pm 18.9^{*}$ & $44.8 \pm 14.1^{*}$ & $1.1(-7.3$ to 9.5$)$ & trivial \\
\hline
\end{tabular}

Note: statistical difference $(p<0.05)$ *between $0-10$ min vs each ten minutes in first half; \# between 0-10 min (I half) comparing to each ten minutes in second half; **between I to II half (30 $\mathrm{min}$ vs $30 \mathrm{~min})$.

The number of change of direction we recorded in six intensity and direction bars are taken in table 2 . The player performed more changing actions when moving left low and right low. These directions of movement also indicate the intensity of movement, which in this case is the smallest in comparison with other intensity zones of movement.

Table 2

Player's Change of Direction (CoD) Movement by the Intensity Direction Bars

\begin{tabular}{lccccc}
\hline \multirow{2}{*}{$\begin{array}{c}\text { IMA CoD } \\
\text { zones }\end{array}$} & $\begin{array}{c}\text { Playing } \\
\text { Time } \\
(\mathbf{m i n})\end{array}$ & $\begin{array}{c}\text { I half } \\
\mathbf{M} \pm \text { SD }\end{array}$ & $\begin{array}{c}\text { II half } \\
\mathbf{M} \pm \text { SD }\end{array}$ & $\begin{array}{c}\text { 95 \% confidence } \\
\text { intervals of the } \\
\text { differences }\end{array}$ & $\begin{array}{c}\text { Effect size } \\
\text { (ES) }\end{array}$ \\
\hline Left Low \\
{$[1.5-2.5 \mathrm{~m} / \mathrm{s}]$} & $0-10$ & $49.0 \pm 25.8$ & $43.7 \pm 27.0$ & $5.4(-6.9$ to 17.7$)$ & trivial \\
\cline { 2 - 6 } & $10-20$ & $37.3 \pm 26.9^{*}$ & $36.0 \pm 24.5^{*}$ & $1.3(-11.7$ to 14.2$)$ & trivial \\
\cline { 2 - 6 } & $20-30$ & $36.6 \pm 25.1^{*}$ & $32.6 \pm 22.7^{*}$ & $4.0(-8.1$ to 16.1$)$ & trivial \\
\cline { 2 - 6 } & total & $41.0 \pm 26.2$ & $37.4 \pm 24.9$ & $3.5(-3.3$ to 10.4$)$ & trivial \\
\hline Left Medium & $0-10$ & $14.3 \pm 7.7$ & $10.8 \pm 6.0^{*}$ & $3.5(0.5$ to 6.5$)$ & small \\
\cline { 2 - 6 }$[2.5-3.5 \mathrm{~m} / \mathrm{s}]$ & $10-20$ & $10.3 \pm 5.7^{*}$ & $9.2 \pm 4.5^{\#}$ & $1.2(-1.6$ to 3.9$)$ & small \\
\cline { 2 - 6 } & $20-30$ & $9.4 \pm 5.9^{*}$ & $8.6 \pm 4.9^{*}$ & $0.8(-1.3$ to 2.9$)$ & small \\
\cline { 2 - 6 } & total & $11.3 \pm 6.7$ & $9.5 \pm 5.2^{* *}$ & $1.8(0.3$ to 3.3$)$ & small \\
\hline
\end{tabular}




\begin{tabular}{|c|c|c|c|c|c|}
\hline $\begin{array}{l}\text { IMA CoD } \\
\text { zones }\end{array}$ & $\begin{array}{l}\text { Playing } \\
\text { Time } \\
\text { (min) }\end{array}$ & $\begin{array}{c}\text { I half } \\
\mathrm{M} \pm \mathrm{SD}\end{array}$ & $\begin{array}{l}\text { II half } \\
M \pm S D\end{array}$ & $\begin{array}{l}95 \% \text { confidence } \\
\text { intervals of the } \\
\text { differences }\end{array}$ & $\begin{array}{l}\text { Effect size } \\
\text { (ES) }\end{array}$ \\
\hline \multirow{4}{*}{$\begin{array}{l}\text { Left High } \\
{[>3.5 \mathrm{~m} / \mathrm{s}]}\end{array}$} & $0-10$ & $5.5 \pm 4.8$ & $4.5 \pm 2.6$ & $1.0(-0.9$ to 2.8$)$ & small \\
\hline & $10-20$ & $3.7 \pm 2.3^{*}$ & $4.1 \pm 2.6$ & $-0.4(-1.9$ to 1.1$)$ & trivial \\
\hline & $20-30$ & $3.2 \pm 2.3^{*}$ & $3.5 \pm 2.5$ & $0.3(-1.5$ to 1.0$)$ & trivial \\
\hline & total & $4.1 \pm 3.5$ & $4.0 \pm 2.5$ & $0.1(-0.8$ to 1.0$)$ & trivial \\
\hline \multirow{4}{*}{$\begin{array}{l}\text { Right Low } \\
{[1.5-2.5 \mathrm{~m} / \mathrm{s}]}\end{array}$} & $0-10$ & $44.1 \pm 24.0$ & $35.8 \pm 20.5$ & $8.3(-1.0$ to 17.5$)$ & small \\
\hline & $10-20$ & $31.6 \pm 25.2^{*}$ & $29.5 \pm 15.9^{\#}$ & $2.1(-4.9$ to 9.1$)$ & trivial \\
\hline & $20-30$ & $30.9 \pm 24.2^{*}$ & $26.5 \pm 14.6^{\#}$ & $4.5(-3.6$ to 12.5$)$ & small \\
\hline & total & $35.5 \pm 24.9$ & $30.6 \pm 17.4^{\star *}$ & $4.9(0.4$ to 9.5$)$ & small \\
\hline \multirow{4}{*}{$\begin{array}{l}\text { Right Medium } \\
{[2.5-3.5 \mathrm{~m} / \mathrm{s}]}\end{array}$} & $0-10$ & $13.3 \pm 7.5$ & $9.1 \pm 5.6^{\#}$ & $4.2(1.5$ to 6.9$)$ & moderate \\
\hline & $10-20$ & $8.8 \pm 4.9^{*}$ & $8.1 \pm 3.8^{\#}$ & $0.7(-1.1$ to 2.4$)$ & small \\
\hline & $20-30$ & $8.5 \pm 5.2^{*}$ & $7.9 \pm 4.9^{\#}$ & $0.5(-1.2$ to 2.2$)$ & trivial \\
\hline & total & $10.2 \pm 6.3$ & $8.4 \pm 4.8^{\star *}$ & $1.8(0.6$ to 3.0$)$ & small \\
\hline \multirow{4}{*}{$\begin{array}{l}\text { Right High } \\
{[>3.5 \mathrm{~m} / \mathrm{s}]}\end{array}$} & $0-10$ & $5.5 \pm 2.8$ & $3.1 \pm 3.4^{\#}$ & $2.4(0.9$ to 3.8$)$ & moderate \\
\hline & $10-20$ & $4.3 \pm 2.5^{*}$ & $4.0 \pm 2.9^{\#}$ & $0.3(-1.1$ to 1.8$)$ & trivial \\
\hline & $20-30$ & $3.9 \pm 2.6^{*}$ & $3.1 \pm 2.6^{\#}$ & $0.8(-0.4$ to 2.0$)$ & small \\
\hline & total & $4.6 \pm 2.7$ & $3.4 \pm 3.0^{\star *}$ & $1.2(0.4$ to 2.0$)$ & small \\
\hline
\end{tabular}

Note: statistical difference $(p<0.05){ }^{\star}$ between $0-10$ min vs each 10 minutes in first half; ${ }^{*}$ between 0-10 min (I half) comparing to each 10 minutes in second half; ${ }^{*}$ between I to II half (30 min vs $30 \mathrm{~min})$.

In the 4 speed zone players covered less distance per time, but we found that statistical difference was between $\mathrm{m} / \mathrm{s}$ in first $10 \mathrm{~min}$ compared to $20 \mathrm{~min}$ and $30 \mathrm{~min}$ of the game in the first half $(\mathrm{p}<0.05)$. The total covered distance in first speed zone $(0.00-1.30 \mathrm{~m} / \mathrm{s})$ during $30 \mathrm{~min}$ (I half) $-223.5 \pm 32.7 \mathrm{~m} / \mathrm{s}$ and (II half) $220.9 \pm 34.3 \mathrm{~m} / \mathrm{s}(\mathrm{p}>0.05$, trivial ES). The second speed zone (1.31-3.00 m/s) during $30 \mathrm{~min}$ (I half) $-372.8 \pm 79.8 \mathrm{~m} / \mathrm{s}$ and (II half) $366.9 \pm 70.7 \mathrm{~m} / \mathrm{s}(\mathrm{p}>0.05$, trivial ES). Third speed zone $(3.01-5.20 \mathrm{~m} / \mathrm{s})$ I half $232.2 \pm 96.0 \mathrm{~m} / \mathrm{s}$ and II half $-208.1 \pm 83.4 \mathrm{~m} / \mathrm{s}(\mathrm{p}>0.05$, small ES). When speed is more than $5.21 \mathrm{~m} / \mathrm{s}$, in I half covered distance was $8.2 \pm 12.3 \mathrm{~m} / \mathrm{s}$, II half $-4.8 \pm 7.1 \mathrm{~m} / \mathrm{s}$ (p > 0.05 , small ES). 


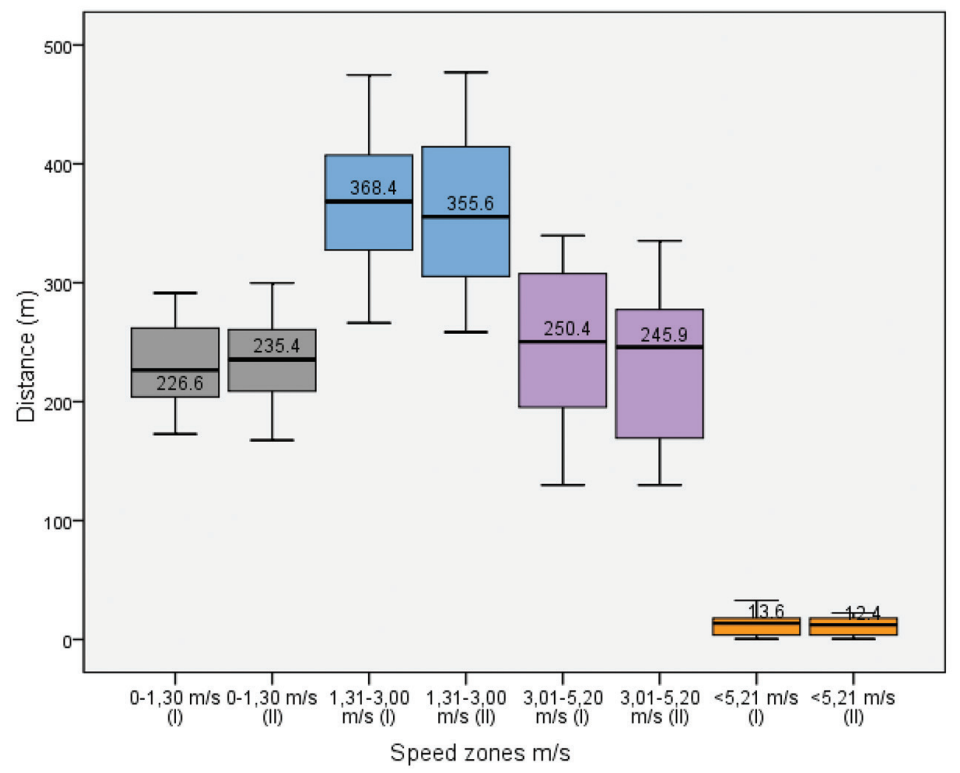

Figure 3. Distances covered in the four speed zones (no statistical difference between 30 vs 30 min, $p>0.05)$. Note - the median is marked in the graph.

Table 3

Distances Covered in Four Speed Zones, when Distances were Measured in Every 10 Minutes of the Match

\begin{tabular}{cccccc}
\hline \multirow{2}{*}{$\begin{array}{c}\text { IMA CoD } \\
\text { zones }\end{array}$} & $\begin{array}{c}\text { Playing } \\
\text { Time } \\
(\mathbf{m i n})\end{array}$ & $\begin{array}{c}\text { I half } \\
\mathbf{M} \pm \text { SD }\end{array}$ & $\begin{array}{c}\text { II half } \\
\mathbf{M} \pm \text { SD }\end{array}$ & $\begin{array}{c}\text { 95\% confidence } \\
\text { intervals of the } \\
\text { differences }\end{array}$ & $\begin{array}{c}\text { Effect } \\
\text { size } \\
\text { (ES) }\end{array}$ \\
\hline \multirow{2}{*}{$0.00-1.30 \mathrm{~m} / \mathrm{s}$} & $0-10$ & $208.2 \pm 30.2$ & $209.4 \pm 32.0$ & $-1.1(-11.7$ to 9.4$)$ & trivial \\
\cline { 2 - 6 } & $10-20$ & $230.6 \pm 35.1^{*}$ & $226.4 \pm 38.3^{\#}$ & $4.2(-10.9$ to 19.3$)$ & trivial \\
\cline { 2 - 6 } & $20-30$ & $232.0 \pm 28.0^{*}$ & $227.2 \pm 30.5^{\#}$ & $4.7(-11.9$ to 21.4$)$ & trivial \\
\hline \multirow{2}{*}{$1.31-3.00 \mathrm{~m} / \mathrm{s}$} & $0-10$ & $399.2 \pm 52.9$ & $389.5 \pm 76.4$ & $10.6(-20.7$ to 41.8$)$ & trivial \\
\cline { 2 - 6 } & $10-20$ & $375.2 \pm 76.7$ & $364.8 \pm 66.8^{\#}$ & $10.4(-25.4$ to 46.1$)$ & trivial \\
\cline { 2 - 6 } & $20-30$ & $375.2 \pm 62.7$ & $347.3 \pm 63.3^{\#}$ & $15.2(-17.5$ to 48.0$)$ & small \\
\cline { 2 - 6 } & $0-10$ & $276.1 \pm 91.0$ & $240.4 \pm 90.3$ & $35.7(-12.2$ to 83.7$)$ & small \\
\cline { 2 - 6 } & $10-20$ & $212.2 \pm 104.6^{*}$ & $190.0 \pm 72.3^{\#}$ & $22.2(-27.8$ to 72.2$)$ & small \\
\hline$>5.21 \mathrm{~m} / \mathrm{s}$ & $20-30$ & $207.1 \pm 78.0^{*}$ & $193.2 \pm 80.5^{\#}$ & $14.0(-38.7$ to 66.6$)$ & trivial \\
\cline { 2 - 6 } & $0-10$ & $18.4 \pm 18.3$ & $7.4 \pm 8.9$ & $10.0(-2.7$ to 22.5$)$ & small \\
\cline { 2 - 6 } & $10-20$ & $8.5 \pm 9.7$ & $4.9 \pm 7.9^{*}$ & $5.2(6.2$ to 16.7$)$ & small \\
\cline { 2 - 6 } & $20-30$ & $8.2 \pm 9.3$ & $5.3 \pm 7.7^{\#}$ & $2.6(-7.4$ to 12.6$)$ & small \\
\hline
\end{tabular}

Note: statistical difference $(p<0.05){ }^{*}$ between $0-10$ min to each 10 minutes in first half; ${ }^{*}$ between 0-10 min (I half) comparing to each 10 minutes in second half. 


\section{Discussion and conclusions}

The results of the research allow us to assess the physical demands of players playing on the court $(40 \times 20 \mathrm{~m})$, their load and effort for the activities in the match. The obtained research data shows that $75 \%$ of handball players cover a distance longer than $790 \mathrm{~m}$, $25 \%$ of handball players run a distance longer than $900 \mathrm{~m}$ (Figure 1). During the 2nd half ( $0-10 \mathrm{~min})$ the longest distance was $950 \mathrm{~m}, 75 \%$ of the players ran in the range from $800 \mathrm{~m}$ to $950 \mathrm{~m}$. During the second 10 minutes $(10-20 \mathrm{~min})$, about $50 \%$ of the handball players ran a distance of more than $800 \mathrm{~m}$ during the first half. What is more, $75 \%$ of the players ran between $790 \mathrm{~m}$ and $980 \mathrm{~m}$. Compared to the second half in the same period, the shortest distance traveled was only $680 \mathrm{~m}$. The average distance of young handball players in a match is $1777 \pm 264 \mathrm{~m}$, and the distance covered by adult handball players in a match is almost double - from $4464 \mathrm{~m}$ to $5088 \mathrm{~m}$ (Chelly, Hermassi, Aouadi, Khalifa, Van, Chamari, \& Shephard, 2011). The players of the court run on average $2882 \pm 1506 \mathrm{~m}$, the goalkeepers $-1377 \pm 293 \mathrm{~m}$, respectively. The sum of the distance covered by the players playing in one position was $5251 \pm 242 \mathrm{~m}$ throughout the match (Manchado, Pers, Navarro, Han, Sung, \& Platen, 2013). Summarizing the distance covered in the match, one can notice that the shortest distance covered during the 1st quarter was $693 \mathrm{~m}$, during the 2nd quarter $-631 \mathrm{~m}$. The longest distance was covered during the first 10 minutes of the first half - $1067 \mathrm{~m}$, during the second half - $983 \mathrm{~m}$. During the second half, taking into account the time distributions every 10 minutes, it was observed that the distance the players ran tended to shorten. The players ran an average distance of $1660 \pm 172 \mathrm{~m}$ during the match. The researchers (Corvino, Vuleta, \& Šibila, 2016) in a study, of a player load while playing games (SSG) 4vs4, it was found that a larger area on the court has an effect on the distance covered by players. For these reasons, it is likely that players were more active in the first minutes of the match when fatigue was not yet felt. However, it can be said, that the individual distance traveled by the players in the match was different.

No less important are the parameters of the players' load, which allow to assess the loads of the players during the game. Moreover, the analysis, done as the playing time changes, shows when the load starts to increase, when it reaches the highest level and at what point in the match it is lowest. The players performed most of the reorientation actions by moving in a upward acceleration (Fig.2). 25\% of their load in the first half, moving vertically, ranged from 65 to 96 AU. Furthermore, during the first 10 minutes of the I-II match quarter, the players' load was the highest. Comparing the data with the change of match time, it was observed that the players' load on all 3 axes tended to decrease. The smallest load was recorded when the players were moving in the forward acceleration. Previous research (Luteberget \& Spencer, 2017) confirmed that the load per minute (PL min - 1) of all players on the court (including the goalkeeper) was $8.82 \pm 2.06 \mathrm{AU}$. If we exclude only the players of the field, their load in the match varies between 9-10 AU. 
Higher player load parameters in the triaxial movement (Table 1) were recorded in the 1st quarter. The average load was 74.3 AU, with the highest being $129.8 \mathrm{AU}$ (1st half). However, a statistically significant difference was found when the players moved on the side axis, the difference in movement between halves was 3.1 (1.0 to 5.3) ( $\mathrm{p}<0.05$, small ES). The highest load on the players was when they moved on the vertical axis (3.6 (-0.7 to 7.9$), p>0.05$, small ES), but this was not a statistically significant difference. Players' load readings revealed that as game time varied, players' load decreased, albeit slightly. Analyzing the parameters of the handball of the wing position in the match, it was found that the greatest load of the player is when moving upwards, less when moving sideways and the least when moving forward (Kniubaite \& Skarbalius, 2015). With this in mind, we should be careful about the players' load parameters, realizing that the positions of the players on the court are different on the court, and therefore the load may be different.

Assessing the quality of players change of directions (CoD's) movement is quite challenging because sports are different in their specifics, and a variety of CoD's tests predominate here (Young, Dawson, Henry, 2015). Players 'CoD's actions are assessed by selecting tests (Sporis, Jukic, Milanovic, Vucetic, 2010) that require the player to demonstrate skills in changing direction. In other words, change of direction $(\mathrm{CoD})$ refers to a pre-planned movement when responding quickly to a situation (Sheppard \& Young, 2006). This requires strength, power, and speed (Asadi et al., 2016). In our study, the change of direction actions of the players was recorded in three different speed zones of movement and by moving in two directions (Table 2). Thus, the change of direction action was recorded mostly when the players moved in the lowest intensity zone $(1.5-2.5 \mathrm{~m} / \mathrm{s})$, left and right. As the players moved left low and right low a statistically significant difference was observed from the 20th minute of the match in both halves. A study by Povoas et al., (2014) found that back players and pivot players perform about $37.9 \pm 9.2$ and $35.4 \pm 11.1 \mathrm{CoD}$ actions in a match, but does not indicate in which directions the players moved. Although it is emphasized that the intensity of players 'actions depends on the position of the game (Karcher \& Buchheit, 2014). This is partly confirmed by our results that players perform a similar or even higher number of actions in matches and different numbers of reversal actions in different lanes. The players' direction of action per minute in the match was $2.6 \pm 1.7 \mathrm{CoD} / \mathrm{min}$ when moving to the left (left low), the number of actions was very similar when moving to the right $(2.2 \pm 1.4 \mathrm{CoD} / \mathrm{min})$. Still, other studies report that adolescent handball players $(15.1 \pm 0.6 \mathrm{~m})$ perform 297 variable actions during matches (Michalsik, 2004). Moreover, when playing games in a reduced pitch area $(24 \times 12 \mathrm{~m})$, players perform an average of $3 \pm 2$ changes of direction (Corvino et al., 2016). Summarizing these actions, it can be said that the players performed a larger number of actions when the intensity zone was smaller, in other words, the more the intensity zones intensified (in $\mathrm{m} / \mathrm{s}$ ), the lower the number of actions in the match. The sum of the number of CoD actions in the match was $200 \pm 128.1$. However, studies on changing actions (CoD) could not be found when analyzed by intensity zones and directions. 
The longest distance was overcome in zone 1, during the I-II quarter it was very similar - the distance was longer than $290 \mathrm{~m}$ (Table 3, fig.5). At least 50\% of the players ran a distance of more than $350 \mathrm{~m}$ in the second half (zone 2). The shortest distance traveled was $254 \mathrm{~m}$. During the second quarter, $25 \%$ of handball players ran a distance of at least $400 \mathrm{~m}$ in this zone, when the running speed is from 1.30 to $3.00 \mathrm{~m} / \mathrm{s}$. In the zone, where the speed ranges from 3.01 to $5.20 \mathrm{~m} / \mathrm{s}$, the longest distance flown during the second quarter decreased by $80 \mathrm{~m}$. However, $75 \%$ of players ran a distance of more than $140 \mathrm{~m}$. The total distance covered was the highest in zone $2(1.30-3.00 \mathrm{~m} / \mathrm{s}) 371.3 \pm 66.1 \mathrm{~m} / \mathrm{s}$ during the first half and $363.6 \pm 72.8 \mathrm{~m} / \mathrm{s}(\mathrm{p}>0,05)-$ in the second half of the match. It can be claimed that the players covered the shortest distance in zone 4 , which is characterized by higher intensity (more than $<5.21 \mathrm{~m} / \mathrm{s}$ ). In this zone, the players covered a shorter distance, but we noticed that there was a significant difference in the first $10 \mathrm{~min}$ compared to the second $10 \mathrm{~min}$ and the third $10 \mathrm{~min}$ of the game in the second half $(\mathrm{p}<0.05$, trivial ES). In the fourth speed zone, when the intensity is $>5.21 \mathrm{~m} / \mathrm{s}$, more than $18 \mathrm{~m}$ were run during the first half and the first 10 minutes. Over the course of the match, the distance traveled decreased in both halves, Corvino and co-authors (2016) analyzed the dynamics of handball players 'unprofessional, load changes with the size of the court. The results of their study revealed that players run a longer distance in Zone $2(635.1 \pm 98.0 \mathrm{~m})$ as well as the second largest distance covered in Zone $3(289.5 \pm 75.2 \mathrm{~m})$ when the court size is $32 \times 16 \mathrm{~m}$. The distance traveled when running $<5.20 \mathrm{~m} / \mathrm{s}$ was the smallest compared to other intensity zones. Al-Lail (2000) reported that elite handball players perform a single acceleration better than $14 \mathrm{~km} / \mathrm{h}$ (i.e., $3.8 \mathrm{~m} / \mathrm{s}$ ) every $44 \pm 17 \mathrm{~s}$. Our players showed the fastest running when the speed reaches $<5.21 \mathrm{~m} / \mathrm{s}$, which is $1.5 \%$ of the distance covered in the match in this speed zone alone $(24.3 \pm 16.5 \mathrm{~m} / \mathrm{s})$. However, we find information that female players spend 0.8 percent of the entire match time running fast and sprinting together (Michalsik, 2015). According to the research data, it is likely that the most optimal speed zone for athletes is the second (1.4-3.4 m / s), for our players the most accurate speed zone is $1.30-3.00 \mathrm{~m} / \mathrm{s}$, where the longest distance was covered in the match. It is the analysis of athletes' physical needs during the competition that allows them to analyze their activities in the match and develop appropriate training programs. Athletes' physical activity during training must correspond to the intensity of the competition (Achten and Jeukendrup, 2003). The analysis of physical needs partly shows the readiness of athletes for matches, because the qualities necessary to win against competitors are strength and power, running, jumping, catching the ball (Hammami, Bragazzi, Hermassi, Gaamouri, Aouadi, Shephard, \& Chelly, 2020). This is confirmed by studies with young (U15) handball players have shown that a 7-week pliometric training program improves jumping, reorientation, and static balance in the pre-competition period (Hammami et al., 2020). A wider range of research analyzing the athletes 'playing activity in different conditions (SSG and / or 40x20 m) creates favorable conditions for organizing the training process according to the athletes' physical demands in preparation for the match. Among other 
things, it is important to take into account the individual positions of the game, when it is known what kind of activity is typical for the players of each of the positions.

Summarizing conclusion. Based on the data obtained and the analysis performed, we can conclude that the physical demands of the players are quite different by time splits of the match.

Given loads of the players, their possible distance in the match, their running speed, can be helpful for the modeling training process, that are close to the load experienced in the match.

The weakest point for players is their speed with a maximum effort, which takes up a very small part of the game time and is not sufficiently developed. Their movement should be adjusted with maximum effort by choosing specific training methods to gain an advantage over opponents. Player load could provide quick information of an athlete's work rate. How much work each player did in a training session compared to previous session or matches. Player monitoring can provide information on changes in the efficiency of player movement, which can be used to take into account the development of the training process. Also, player workloads are important for information about player capabilities, it is just one of many criteria in organizing a training process, and the load progress should still be monitored.

The maximum load on the players is as they move in the upward acceleration; The optimal intensity of movement is determined in the 2nd speed zone $(1.30-3.00 \mathrm{~m} / \mathrm{s})$, when the maximum distance in the match, which is close to the distance covered by the handball player (s) of their age, is covered. Data on player workload, distance traveled during a match may be useful to manual coaches or physical training coaches, who can use these parameters to select specific training methods that match the intensity of the match.

\section{Limitations of the research}

In order to achieve a more favorable outcome of the match, it would be useful to find out what influence a known competitor has on the players' preparation for the competition, to look for ways to prepare for it. The basis of our study is a simulation game, as the availability of equipment is limited, this was the choice. However, one of the modeling variations of the study in the future could be - the activity of the players is analyzed during the competition during the championship, taking into account their positions on the field. It could have implications the choice of match strategies and tactical decisions in handball play. 


\section{References}

Achten, J., \& Jeukendrup, A. E. (2003). Heart rate monitoring: applications and limitations. Sports Medicine, 33(7), 517-538.

Al-Lail, A. (2000). A motion analysis of work-rate and heart rate of elite Kuwaiti handball players. Asian Handball Federation. Kuwait: Commission for Promotion \& Public Relations IHF.

Asadi, A., Arazi, H., Young, W. B., \& de Villarreal, E. S. (2016). The effects of polymeric training on change-of-direction ability: A meta-analysis. International Journal of Sports Physiology and Performance, 11(5), 563-573.

Borg, G. (1990). Psychophysical scaling with applications in physical work and the perception of exertion. Scandinavian Journal of Work, Environment \& Health, 55-58.

Chelly, M. S., Hermassi, S., Aouadi, R., Khalifa, R., Van, D. T., \& Chamari, K., \& Shephard, R. J. (2011). Match analysis of elite adolescent team handball players. Journal of Strength and Conditioning Research (Lippincott Williams \& Wilkins), 25(9), 2410-2417.

Corvino, M., Vuleta, D., \& Šibila, M. (2016). Analysis of load and player's effort in 4 vs 4 smallsided handball games in relation to court dimensions. Kinesiology: International Journal of Fundamental and Applied Kinesiology, 48(2), 213-222.

Coutts, A. J. (2010). Validity and reliability of GPS devices for measuring movement demands of team sports. Journal of Science and Medicine in Sport, 13(1), 133-135.

Michalsik, L. B. (2004). Analysis of working demands of Danish handball play-ers In: Jørgensen, P., Vogensen, N. (Eds.), What going on in the gym? Learning, teaching and research in physical education. Proceedings of International Conference on PE-teaching, Learning and Research, Denmark: University of Southern Denmark, 321-330.

Gorostiaga, E. M. (2006). Effects of an entire season on physical fitness changes in elite male handball players. Medicine Science in Sports and Exercise, 38(2), 357-366.

Hammami, M., Bragazzi, N. L., Hermassi, S., Gaamouri, N., Aouadi, R., Shephard, R. J., \& Chelly, M. S. (2020). The effect of a sand surface on physical performance responses of junior male handball players to plyometric training. BMC Sports Science, Medicine and Rehabilitation, 12(1), 1-8.

Hatzimanouil, D., Giatsis, G., Kepesidou, M., Kanioglou, A., \& Loizos, N. (2017). Shot effectiveness by playing position with regard to goalkeeper's efficiency in team handball. Journal of Physical Education and Sport, 17(2), 656-662.

Hopkins, W. G. (2006). Magnitude maters: Effect size in research and clinical practice. Medicine and Science In Sports and Exercise, 38(5), 56-60.

Jones, M. R., West, D. J., Crewther, B. T., Cook, C. J., \& Kilduff, L. P. (2015). Quantifying positional and temporal movement patterns in professional rugby union using global positioning system. European Journal of Sport Science, 1-9.

Karcher, C. (2014). On-court demands of elite handball, with special reference to playing positions. Sports Medicine, 44(6), 797-814. 
Laver, L., Landreau, P., Seil, R., \& Popovic, N. (Eds.). (2018). Handball Sports Medicine: Basic science, injury management and return to sport. Springer. Retrieved from: https://www. springer.com/gp/book/9783662558911

Luteberget, L. S., \& Spencer, M. (2017). High-intensity events in international women's team handball matches. International Journal of Sports Physiology and Performance, 12(1), 56-61.

Manchado, C., Pers, J., Navarro, F., Han, A., Sung, E., \& Platen, P. (2013). Time-motion analysis in women's team handball: importance of aerobic performance. Journal of Human Sport and Exercise, 8 (2), 376-390.

Michalsik, L. B. (2011). Match performance and physiological capacity of male elite team handball players. Vienna: European Handball Federation, 162-168.

Michalsik, L. B., \& Aagaard, P. (2015). Physical demands in elite team handball: comparisons between male and female players. The Journal of Sports Medicine and Physical Fitness, 55(9), 878-891.

Michalsik, L. B., Aagaard, P., \& Madsen, K. (2013). Locomotion characteristics and match-induced impairments in physical performance in male elite team handball players. International Journal of Sports Medicine, 34(07), 590-599.

Michalsik, L. B., Madsen, K., \& Aagaard, P. (2014). Match performance and physiological capacity of female elite team handball players. International Journal of Sports Medicine, 35(7), 595-607.

O’ Donoghue, P. (2014). An introduction to performance analysis of sport. London: Routledge.

Onusaitytè, G., \& Skarbalius, A. (2009). Didelio meistriškumo rankininkès įžaidèjos darbo intensyvumo kaita rungtyniaujant. Baltic Journal of Sport and Health sciences, 2(73) 80-85.

Pokrajac, B. (2010). Handball tendency regarding results analysis European Championship 2008 and World Championship 2009. EHF Periodical. Retrieved from: http://home.eurohandball. com/ehf_files/Publikation/Pokrajac\%20Analysis_091204.pdf.

Póvoas, S. C., Seabra, A. F., Ascensão, A. A., Magalhães, J., Soares, J. M., Rebelo (2012). Physical and physiological demands of elite team handball. The Journal of Strength \& Conditioning Research, 26 (12), 3365-3375.

Serpiello, F. R., Hopkins, W. G., Barnes, S., Tavrou, J., Duthie, G. M., Aughey, R. J., \& Ball, K. (2018). Validity of an ultra-wideband local positioning system to measure locomotion in indoor sports. Journal of Sports Sciences, 36(15), 1727-1733.

Sheppard, J. M., \& Young, W. B. (2006). Agility literature review: Classifications, training and testing. Journal of Sports Sciences, 24(9), 919-932.

Sporis, G., Jukic, I., Milanovic, L., \& Vucetic, V. (2010). Reliability and factorial validity of agility tests for soccer players. The journal of Strength \& Conditioning Research, 24(3), 679-686.

Young, W. B., Dawson, B., \& Henry, G. J. (2015). Agility and change-of-direction speed are independent skills: Implications for training for agility in invasion sports. International Journal of Sports Science and Coaching, 10(1), 159-169. 


\title{
Jaunučių rankininkių fizinių poreikių kaita žaidimo metu
}

\author{
Rasa Mikalonyte் $\dot{1}^{1}$ Rūtenis Paulauskas ${ }^{2}$
}

Vytauto Didžiojo Universitetas, Švietimo akademija, T. Ševčenkos g. 31, LT-03111 Vilnius, rasa.mikalonyte@vdu.lt

Vytauto Didžiojo Universitetas, Švietimo akademija, T. Ševčenkos g. 31, LT-03111 Vilnius, rutenis.paulauskas@vdu.lt

\section{Santrauka}

Tyrimo tikslas - įvertinti jaunųjų rankininkių fizines pastangas, atliekant žaidèjų judèjimo analizę vienų rungtynių metu. Šiame tyrime dalyvavo 28 jaunosios rankinio žaidejjos $(\mathrm{n}=28)$. Komandos žaidè rankini pagal tarptautinès rankinio federacijos (angl. IHF - International handball federation) taisykles. LPS (angl. local positioning system) žaidejjų stebèjimo prietaisu (Optime Eye X4 Catapult, Australia) žaidimo metu buvo fiksuojami žaidejjų fiziniai parametrai. Buvo užfiksuotas bendras įveiktas atstumas (m), žaidejjų apkrovos (sąlyginiais vienetais (SV)), žaidejjų apkrovos per minutę, žaidejjų apkrovos judant triašèje plokštumoje (SV), krypčių keitimo skaičius (angl. CoD-change of directions), ivveiktas atstumas 4 greitumo zonose (m). Apibrěžtieji statistiniai duomenys buvo naudojami apskaičiuojant vidurkius ir standartinius nuokrypius, t-testą reikšmingumo lygiu $\mathrm{p}<0,05$.

Gauti tyrimo duomenys rodo, kad 75 proc. rankininkių ịveikia nuotolị, ilgesnị nei $790 \mathrm{~m}$, per rungtynes įveikè vidutiniškai $1660 \pm 172$ m nuotolį. Pasiekè didžiausią greitị $(>5,21 \mathrm{~m} / \mathrm{s})$, tai sudaro 1,5 proc. rungtynėse įveikto atstumo bėgant $24,3 \pm 16,5 \mathrm{~m} / \mathrm{s}$. Taip pat buvo nustatyta, kad žaidejų didžiausia apkrova yra joms judant vertikalioje plokštumoje. Optimaliausias judejjimo intensyvumas nustatytas 2-oje greitumo zonoje (1,30-3,00 m/s), kai įveikiamas didžiausias nuotolis rungtynėse, kuris yra artimas jų amžiaus rankininkių įveikiamam atstumui.

Duomenys apie žaidejjų krūvị, ìveiktus atstumus žaidžiant gali būti naudingi rankinio treneriams ar fizinio parengtumo treneriams, kurie gali naudoti šiuos parametrus pasirinkdami konkrečius treniruočių metodus pagal žaidejjų fizinius poreikius. Žaidejjų krūvio duomenys yra svarbūs norint sužinoti individualias žaidejjų fizines galimybes, nustatant, kiek darbo konkrečioje veikloje (treniruoteje, rungtynèse) jie atliko. Kitaip tariant, žaidèjų krūvis atspindi jų judejjimo efektyvumą, ir tai gali būti vienas iš žaidèjų veiklos stebejjimo kriterijų, padedančių organizuoti bei stebèti treniruočių procesą.

Esminiai žodžiai: komandinis sportas, LPS (angl. local positioning system) sistema, atstumas metrais, greitumo zonos. 